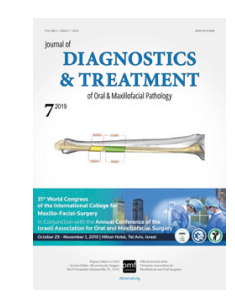

Analytics of Journals and Publishers

\title{
Comparison of Article Processing Fees on Open Access Journals with a 4.5-Year History of Publishing
}

\author{
Daniel Robles Cantero ${ }^{a}$, Todd R. Schoenbaum , Zinaida Y. Zhehulovych, \\ Ivan V. Nagorniakd, * \& levgen I. Fesenko, *
}

\section{SUMMARY/INTRODUCTION}

Open access article (synonym: open access publication) is a type of peer-reviewed article which gives a possibility to the readers to read and download it free of charge owing to paying an open access publication fee (OAPF) directly by its authors, their institutions, or funders. ${ }^{1}$ According to Solomon and Björk's study, who analyzed about 1,370 journals, article processing charges range from 8 to 3,900 US Dollars. ${ }^{1,2}$ Moreover, the official Elsevier's page dedicated to the list of all company's open access journals indicated that an article processing charge can reach 6,000 US Dollars excluding tax. ${ }^{3}$ First publishing houses that supported and develop open access journals have been two new academic publishers - BioMed Central (BMC) and Public Library of Science (PLoS). ${ }^{1}$ In 2000, they began establishing journals that rely on open access publication fee. ${ }^{1}$ Most motivation criteria for the authors from the fields of oral and maxillofacial surgery, periodontics in choosing to what peer-reviewed journal submit their paper may be classified under three chief groups: 1) indexing and abstracting in different recognized data bases (PubMed/ Medline, ${ }^{4}$ Scopus, Web of Science, etc.), 2) an impact metric, ${ }^{5}$ and 3) an amount of the article processing charge. First two motivation criteria are precisely described in recent publications but the last one - open access publication fee and its amount - should be investigated more scrupulously. ${ }^{4,5}$ There is a great need to analyze the advantages and disadvantages of OAPF both for authors and editorial staff/publishers. This is the aim of this study in order to understand the advantages and disadvantages the payment

a DDS, MSc, Clinical Director of Miguel de Cervantes European University, Co-director in Master of Periodontology and Implantology of UEMC. Private Oral Surgery Practice, Madrid, Spain

${ }^{b}$ DDS, FACD, Associate Clinical Professor, UCLA Division of Constitutive \& Regenerative Sciences; Director, UCLA Continuing Dental Education, University of California, Los Angeles (UCLA), CA, USA

c ScD, Professor, Department of Dentistry, Institute of Postgraduate Education, Bogomolets National Medical University, Kyiv, Ukraine

${ }^{d}$ Oral Surgeon, PhD, Private Dental Practice, Kyiv, Ukraine

e PhD, Assistant Professor. Department of Oral \& Maxillofacial Surgery, Private Higher Educational Establishment "Kyiv Medical University"

${ }^{*}$ Corresponding authors: Private Dental Practice (certificate for management system according to ISO 9001:2015 - Private entrepreneur Nagorniak I.V.), 6-G Andruschenka Street, Office 6, Kyiv 01135, Ukraine.

Phone: +38 (067) 4088131

E-mail address: ivan.nagorniak@gmail.com (Ivan Nagorniak)

Department of Oral \& Maxillofacial Surgery, Private Higher Educational Establishment "Kyiv Medical University"

7 Antona Tsedika Street, Kyiv 02000, Ukraine.

E-mail: i.i.fesenko@dtjournal.org (levgen Fesenko)

Instagram: dr_eugenfesenko

E-mail: tschoenb@ucla.edu (Todd Schoenbaum) Instagram: todd schoenbaum

E-mail:drobles@clinica.uemc.es (Daniel Robles Cantero) Instagram: robles drc

E-mail: zhegulovih@gmail.com (Zinaida Zhehulovych)

Paper received 14 July 2019

Accepted 26 July 2019

Available online 31 July 2019

http://dx.doi.org/10.23999/j.dtomp.2019.7.3

(C) 2019 OMF Publishing, LLC. This is an open access article under the CC BY license (http://creativecommons.org/licenses/by-nc/4.0/). 
methods. For the purpose of comparative analysis we selected two peer-reviewed journals according to the following inclusion criteria:

1. Fully open access publication (hybrid or delayed open access journals were excluded during selection).

2. Similar term of publication history - about 5 years (similar starting point allows comparing the peer-reviewed journals more precisely).

3. Journals focused on oral surgery.

4. Different ways of receiving article processing charges after the submission of manuscripts.

5. English, as language of publications.

Analysis was performed on the publishing statistics, abstracting and indexation of the journals as important characteristics of the ways of growth of both peer-reviewed publications.

\section{MATERIALS \& METHODS}

Two journals were selected, the Oral and Maxillofacial Surgery Cases and International Journal of Implant Dentistry. For analysis, we have compared: 1) presentation forms of the journals: print and electronic, 2) media platforms of the publishers, 3) editorial boards, 4) portfolio of the articles, 5) publication frequency, systematization on issues and volumes, 6) comparison of abstracting and indexing of the journals, and 7) article processing charges. We performed analysis using open data from websites of the journals and the publishers.

\section{JOURNALS`PRESENTATION}

Oral and Maxillofacial Surgery Cases is an English-language online-only open access journal focused on publishing case reports and case series in the field of oral and maxillofacial surgery. ${ }^{6}$ The journal's first issue was published by Elsevier company in March 2015 and included 4 case report articles showing an international approach the publications' origin. The first issue had authors from Canada, USA, Ghana, and Sweden..$^{7-10}$ During 4.5 years of journal's growth the total amount of published articles reached 97 peerreviewed publications (Table 1). The strongest was 2018 when totally 31 articles were published in the journal under guidance of 17 members of editorial board (Table 2). The OAPF for the authors of Oral and Maxillofacial Surgery Cases is 500 US dollars. That is $\$ 160$ less than the average per-article charge for open-access publishers in 2011 when it was $\$ 660 .^{2}$ The journal is covered from 2015 by Elsevier's Scopus database (Fig 1). ${ }^{11}$ According to the SCImago Journal Rank of 2018 (Table 3), the journal Oral and Maxillofacial Surgery Cases is thirty-fifth place among 47 journals in the category 'oral surgery', and seventyeight place among 109 journals in the category 'otorhinolaryngology'. The journal's CiteScore in 2018 was 0.41 , Source Normalized Impact per Paper (SNIP) 0.719, and SCImago Journal Rank $0.208{ }^{11,12}$ All issues of this quarterly journal are included in the Directory of Open Access Journals (DOAJ). ${ }^{13}$ For Oral and Maxillofacial Surgery Cases Elsevier has a tool for the authors and readers. At ScienceDirect webpage, the term 'articles in press' (Table 4) means the accepted, peer-reviewed papers that are not yet assigned to issues/volumes, but are citable using digital object identifier (DOI). ${ }^{14}$ Generally, there are 3 types of articles in press: accepted manuscripts, uncorrected proofs, and corrected proofs. ${ }^{14}$ Articles in press's tool is similar to Online First Publication tool in some Springer`s journals.

International Journal of Implant Dentistry was launched in December 2015 by the collaborative efforts of German Association of Dental Implantology (in German, Deutsche Gesellschaft für Implantologie - DGI) and the Japanese Society of Oral Implantology (JSOI) on the SpringerOpen platform of the Springer Nature company. ${ }^{15}$ It's an online-only (Table 5) peer-reviewed journal focused on implantology. Despite the fact that national languages of those societies are German and Japanese, the journal uses English. ${ }^{15-18}$ Editors in chief, Hendrik Terheyden and Yoshinobu Maeda, stated that totally more than 20,000 persons are the members of both societies. ${ }^{19}$ That fact can impact the journal's growth and popularization. The preconditions that guided the editors before the launch of the new peer-reviewed journal were: 1) implant dentistry as a growing field, 2) quick publishing (no waiting of printing deadlines), 3) open access structure of all articles, 4) rapid spread 
TABLE 1. Published Articles per Year.

\begin{tabular}{|c|c|c|}
\hline Years & $\begin{array}{c}\text { Oral and Maxillofacial } \\
\text { Surgery Cases }\end{array}$ & $\begin{array}{c}\text { International Journal of Implant } \\
\text { Dentistry }\end{array}$ \\
\hline 2015 & 14 & 26 \\
\hline 2016 & 9 & 27 \\
\hline 2017 & 21 & 50 \\
\hline 2018 & 31 & 41 \\
\hline $\begin{array}{c}\text { 6 months of 2019 } \\
\text { (from Januar 01 to July 01) }\end{array}$ & 22 & 24 \\
\hline Total & 97 & 168 \\
\hline
\end{tabular}

TABLE 2. Comparison of Number of Editorial Boards ` Persons and Countries of Their Origin.

\begin{tabular}{|c|c|c|}
\hline & $\begin{array}{c}\text { Oral and Maxillofacial } \\
\text { Surgery Cases }\end{array}$ & $\begin{array}{c}\text { International Journal of } \\
\text { Implant Dentistry }\end{array}$ \\
\hline \multicolumn{3}{|c|}{ Editorial Board } \\
\hline Editors in Chief & 1 person & 2 persons \\
\hline Editorial Board members & 16 persons & 39 persons \\
\hline Total & 17 persons & 41 persons \\
\hline \multicolumn{3}{|c|}{ Origin of Editorial Board Members } \\
\hline Number of Countries & 1 & 18 \\
\hline List of Countries & USA & $\begin{array}{c}\text { Japan } \\
\text { Germany } \\
\text { Canada } \\
\text { Brazil } \\
\text { Spain } \\
\text { Hong Kong, SAR } \\
\text { USA } \\
\text { Italy } \\
\text { Australia } \\
\text { South Korea } \\
\text { Austria } \\
\text { Netherlands } \\
\text { South Africa } \\
\text { United Kingdom } \\
\text { Switzerland } \\
\text { Sweden } \\
\text { Singapore } \\
\text { China } \\
\end{array}$ \\
\hline
\end{tabular}


COMPARISON OF TWO OPEN-ACCESS JOURNALS WITH 4.5-YEAR HISTORY OF PUBLISHING

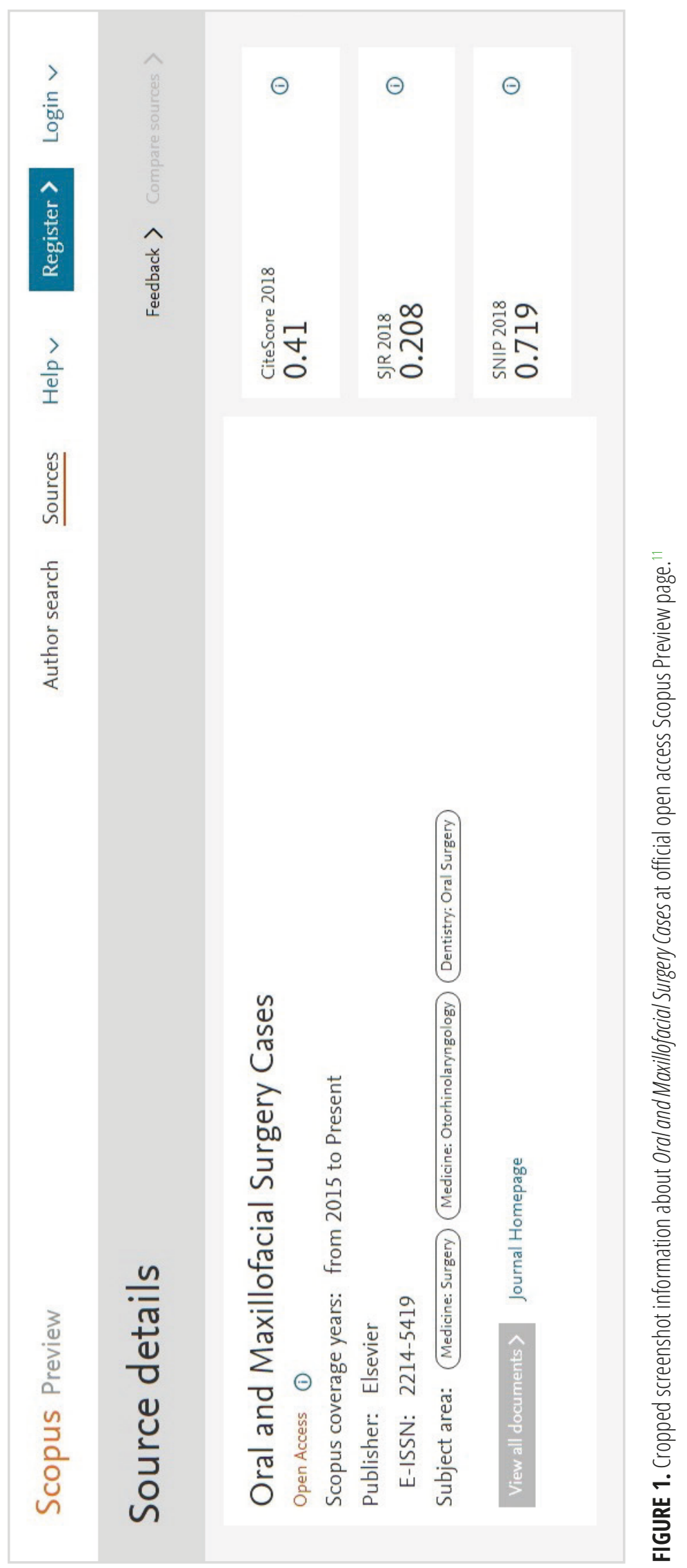


TABLE 3. Comparison of Covering by the Abstract and Citation Databases, Web-Based Search Systems, and Indexing of the Journals.

\begin{tabular}{|c|c|c|}
\hline Abstracting and Indexing & $\begin{array}{c}\text { Oral and Maxillofacial } \\
\text { Surgery Cases }\end{array}$ & $\begin{array}{l}\text { International Journal of } \\
\text { Implant Dentistry }\end{array}$ \\
\hline $\begin{array}{c}\text { Directory of Open Access } \\
\text { Journals (DOAJ) }\end{array}$ & Included $^{13}$ & Included $^{13}$ \\
\hline PubMed/MEDLINE & - & Included to PubMed ${ }^{26}$ (Fig 2) \\
\hline Google Scholar & - & - \\
\hline Scopus & $\begin{array}{l}\text { Covered from } 2015 \text { to } \\
\text { Present }^{11} \text { (Fig 1) }\end{array}$ & - \\
\hline CiteScore & 0.41 & - \\
\hline $\begin{array}{c}\text { Source Normalized Impact } \\
\text { per Paper (SNIP) }\end{array}$ & 0.719 & - \\
\hline SCImago Journal Rank (SJR) & 0.208 & - \\
\hline Quartile according to SJR & Third quartile (Q3) & - \\
\hline Web of Science & - & - \\
\hline Impact Factor & - & - \\
\hline
\end{tabular}

TABLE 4. Articles in Press (Elsevier)/Online First Publication (Springer Nature) Options.

\begin{tabular}{|c|c|c|}
\hline Options of the Publishers & $\begin{array}{c}\text { Oral and Maxillofacial } \\
\text { Surgery Cases (Elsevier) }\end{array}$ & $\begin{array}{c}\text { International Journal of Implant } \\
\text { Dentistry (Springer Nature) }\end{array}$ \\
\hline $\begin{array}{c}\text { Articles in Press (Elsevier)/ } \\
\text { Online First Publication } \\
\text { (Springer Nature) }\end{array}$ & Yes & Yes \\
\hline
\end{tabular}

TABLE 5. Comparison of Types of Publishing: Print and Electronic.

\begin{tabular}{|c|c|c|}
\hline Versions of the Publication & $\begin{array}{c}\text { Oral and Maxillofacial } \\
\text { Surgery Cases }\end{array}$ & $\begin{array}{c}\text { International Journal of } \\
\text { Implant Dentistry }\end{array}$ \\
\hline Print version & No & No \\
\hline Online (electronic) version & Yes & Yes \\
\hline
\end{tabular}

of information, and 5) publishing fees are granted by the association and society (Table 6). ${ }^{15}$ The journal and publisher (Springer company) using SpringerOpen platform ${ }^{15}$ had published 7 articles during the first quarter of 2015. First issue had authors from Germany, Japan, USA, Sweden, India, and Netherlands. ${ }^{20-25}$ The articles are published every month, and they are published as they are prepared (Table 7). The most robust year in development was
2017 when 50 articles have been published (Table 1). After inclusion in DOAJ, ${ }^{13}$ covered by PubMed ${ }^{26}$ (Fig 2), the journal increased its attractiveness for authors (Table 3). ${ }^{4}$ Three main editorial board's differences comparing Oral and Maxillofacial Surgery Cases with International Journal of Implant Dentistry are 1) two editors in chief (Tables 2), 2) two-times more members, and 3) members are from eighteen countries. 
TABLE 6. Comparison of Publication Payment Methods in Two Open Access Journals. 6, 15

\begin{tabular}{|c|c|c|}
\hline $\begin{array}{l}\text { Criteria for } \\
\text { Comparison }\end{array}$ & $\begin{array}{c}\text { Oral and Maxillofacial } \\
\text { Surgery Cases }\end{array}$ & International Journal of Implant Dentistry \\
\hline Publisher's Name & Elsevier & Springer Nature \\
\hline $\begin{array}{l}\text { Type of Access to } \\
\text { Articles }\end{array}$ & Open Access & Open Access \\
\hline Publication Fee & US\$500 (excluding tax) & $\begin{array}{l}\text { Absent. Fee is covered by two affiliated } \\
\text { societies: } \\
\text { - German Society of Oral Implantology: } \\
\text { In German, Deutsche Gesellschaft für } \\
\text { Implantologie (DGI). } \\
\text { - Japanese Society of Oral Implantology } \\
\text { (JSOI): In Japanese, Nihon Kōkū } \\
\text { Inpuranto Gakkai. }\end{array}$ \\
\hline
\end{tabular}

TABLE 7. Publication Frequency, Systematization on Issues and Volumes.

\begin{tabular}{|c|c|c|}
\hline $\begin{array}{l}\text { Criteria for } \\
\text { Comparison }\end{array}$ & $\begin{array}{c}\text { Oral and Maxillofacial Surgery } \\
\text { Cases }\end{array}$ & $\begin{array}{c}\text { International Journal of Implant } \\
\text { Dentistry }\end{array}$ \\
\hline $\begin{array}{l}\text { Publication } \\
\text { Frequency }\end{array}$ & $\begin{array}{l}\text { Quarterly: articles are published } \\
\text { every } 3 \text { months. }\end{array}$ & $\begin{array}{l}\text { Monthly: articles are published every } \\
\text { month; they are published as they are } \\
\text { prepared. }\end{array}$ \\
\hline $\begin{array}{l}\text { Systematization } \\
\text { on Issues and } \\
\text { Volumes }\end{array}$ & $\begin{array}{l}\text { Each article received a number and is } \\
\text { assigned an affiliation to a particular } \\
\text { issue (number) in the volume. } \\
\text { Example: Khanifama P, Pullisaarb } \\
\text { H, Risheimc H. Local } \\
\text { facial atrophy and } \\
\text { permanent anesthesia of } \\
\text { right upper lip following } \\
\text { subcutaneous extrusion of } \\
\text { chlorhexidine digluconate. } \\
\text { Oral Maxillofac Surg Cases } \\
2019 ; 5(1): 100087 . \\
\text { Whereas, ' } 5 \text { ' is a volume, ' } 1 \text { ' is an } \\
\text { issue, and '100087' is an article's } \\
\text { number. }\end{array}$ & $\begin{array}{l}\text { Each article received a number and } \\
\text { is assigned an affiliation only to the } \\
\text { particular volume. } \\
\text { Example: Gnigou M, Goutzanis } \\
\text { L, Sarivalasis S, Petsinis } \\
\text { V. Retrieval of displaced } \\
\text { implants inside the maxillary } \\
\text { sinus: two case reports and a } \\
\text { short review. Int J Implant } \\
\text { Dent } 2019 ; 5: 24 \text {. } \\
\text { Whereas, ' } 5 \text { ' is a volume and } \\
\text { ' } 24 \text { ' is an article's number. }\end{array}$ \\
\hline
\end{tabular}




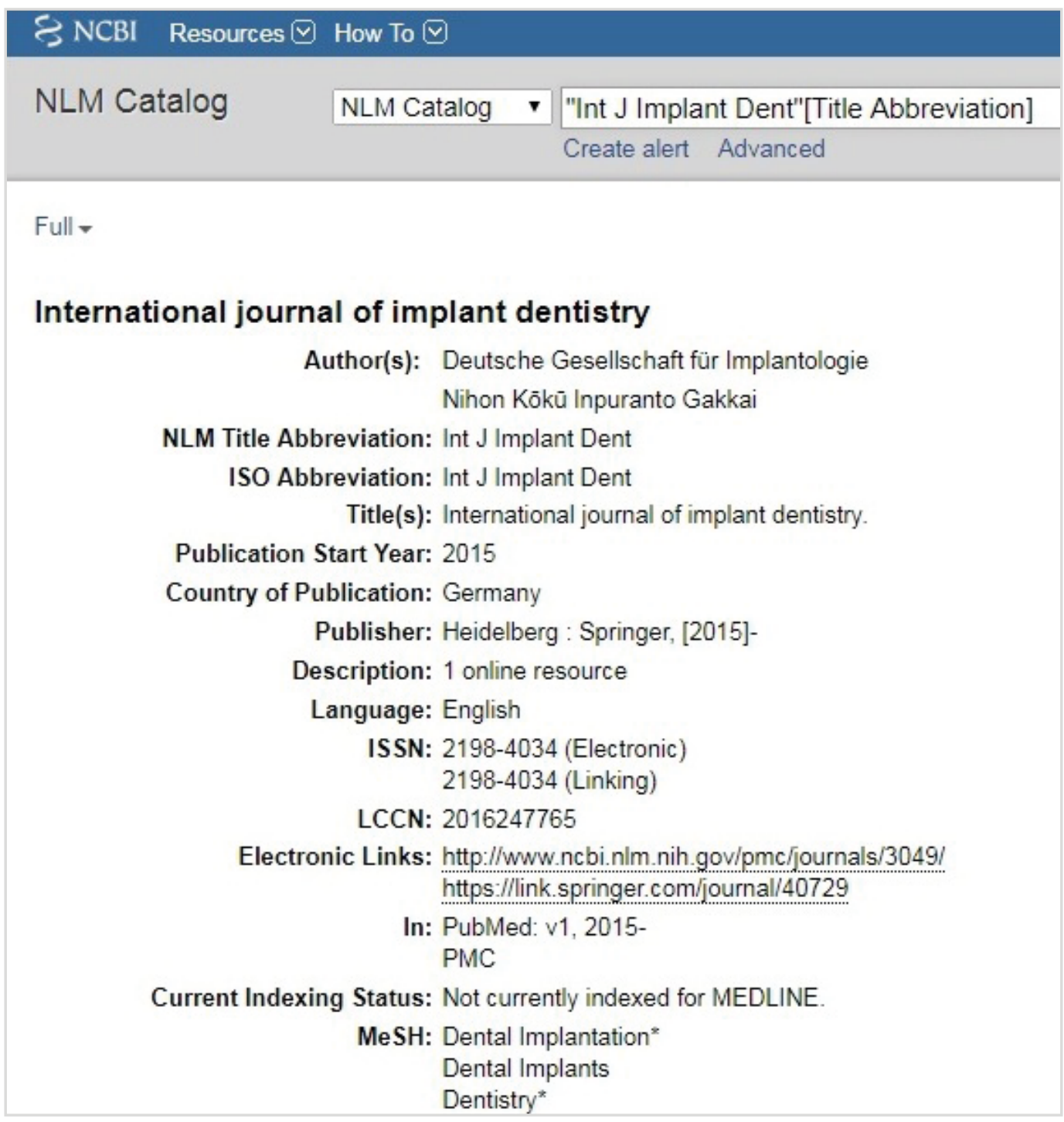

FIGURE 2. Cropped screenshot information from catalog page of International Journal of Implant Dentistry at National Library of Medicine (NLM) website. 25 


\section{DISCUSSION}

Better understanding of every step of the journals' growth `s is possible by analyzing journals ' results in including to the different citation and abstract databases. Those databases are playing a crucial role in the struggle of editorial staff to attract more authors, to reduce acceptance rate and to achieve an increase of the impact metric as a result. . $^{27-29}$

This paper presents a comparative study of Oral and Maxillofacial Surgery Cases and International Journal of Implant Dentistry. ${ }^{6,15}$ Analyzing the example of International Journal of Implant Dentistry we can assume that when the journal offers no publication fee it attracts more authors, and that potentially can result in increased number of articles submission. Second hypothesis: abstracting in PubMed/MEDLINE plays a crucial role for authors in choosing the "right" journal for submission. ${ }^{4,}{ }^{30}$ That step potentially will bring the authors' paper to the advantageous position in the global market of published articles. A larger number of published articles in International Journal of Implant Dentistry comparing to Oral and Maxillofacial Surgery Cases can be an argument of our assumption. This theory can be considered valid by the June's editorial of Ophthalmology Retina editor Andrew Schachat. ${ }^{4}$ He considers the question "Is the journal included to PubMed?" will be among the first and the most persistent question. ${ }^{4}$ We can say the same, taking into account the 2.5 -year editorial office experience in Journal of Diagnostics and Treatment of Oral and Maxillofacial Pathology for a question about covering by PubMed being the top question among authors from Australia, Brazil, and India prior to submission. Similarly, editors of Plastic and Reconstructive Surgery-Global Open insist that being indexed in PubMed is a huge milestone for their relatively new sister journal. ${ }^{30}$ From the moment of being covered by PubMed their journal became more discoverable and visible. ${ }^{30}$ We understand that efforts of the editorial board members and editors should be also measured, but many of the efforts belong to the subjective criteria and we can measure only superficial layer of official open data (Tables 1-7 and Figs 1,2). Another group of authors can be attracted by the fact that journal is covered by Scopus database ${ }^{11,12}$ with calculation of CiteScore, ${ }^{31}$ Source Normalized
Impact per Paper (SNIP) ${ }^{32}$ and assigning to the journal a specific position in SCImago Journal Rank $^{33,12}$ and a certain quartile. In that case, existence of as high OAPF as US $\$ 500$ cannot stop authors from submission a manuscript to Oral and Maxillofacial Surgery Cases. ${ }^{6}$

As impact factor is still the common requirement in most European medical institutions it also plays a significant role in the decision of authors to what journal to submit the paper. ${ }^{5}$ Nevertheless, in our study we did not find any information weather both journals have an impact factor. ${ }^{6,15}$

In conclusion: both journals are online only, English-language open access publications, related with an 'oral surgery' field, and with an internationally diverse portfolio of papers. Both are included to the Directory of Open Access Journals (DOAJ). Their four main differences are: 1) presence of an association/society that is holding the publication as the official journal of the community, 2) journal's inclusion to the different abstracting databases, 3) article processing charge models, and 4) editorial board list. Within the limits of this study, we try to hypothesize the ways of achieving attractiveness by the journals with nearly equal periods of publication. Understanding the diversity of authors ' requirements in the search for journals for open access publications, and difficulties in a precise comparison of both journals one cannot unambiguously determine the main driving force of author's choice. All obtained comparative data, on one hand, allow only approximation of the differences in journals ' attractiveness, and, on the other hand, allow the precise measurement of steps in the evolution of publications. Taking into account the tendencies in the rapidly changing market of open access journals, further investigations in the field of open access publications and its' attractiveness for authors are strongly recommended.

\section{ROLE OF THE AUTHORS}

Daniel Robles Cantero (editing)

Todd R. Schoenbaum (reviewing and editing)

Zinaida Y. Zhehulovych (editing)

Ivan V. Nagorniak (concept and design of the paper and material collection)

Ievgen I. Fesenko (concept and design of the paper and writing) 


\section{ACKNOWLEDGMENTS}

The co-authors of the article express deep respect to Dr. Schoenbaum for the fundamental approach to editing this article.

\section{REFERENCES}

1. Solomon DJ, Björk B-C. A study of open access journals using article processing charges. $J$ Assoc Inf Sci Technol 2012;63:1485-95. https://dx.doi. org/10.1002/asi.22673.

2. Van Noorden R. Open access: the true cost of science publishing. Nature 2013;495(7442):426-9. https:// doi.org/10.1038/495426a.

3. Open access journals [document on the internet]; 2019 [cited 2019 Jul 20]. Available from: https://www. elsevier.com/about/open-science/open-access/openaccess-journals.

4. Schachat AP. Ophthalmology Retina is now indexed in MEDLINE/PubMed.OphthalmolRetina 2019;3:457-58. https://dx.doi.org/10.1016/j.oret.2019.04.012.

5. Verma IM. Impact, not impact factor. Proc Natl Acad Sci USA 2015;112:7875-6. https://dx.doi. org/10.1073/pnas.1509912112.

6. Oral and Maxillofacial Surgery Cases [document on the internet]; 2019 [cited 2019 Jul 18]. Available from: https://www.journals.elsevier.com/oral-andmaxillofacial-surgery-cases/.

7. AboSharkh H, Nahal A, Suliman Zaid W, El-Hakim M. Nodular fasciitis in the masticator space eroding into the mandible: a case report. Oral Maxillofac Surg Cases 2015;1:1-4. https://dx.doi.org/10.1016/j. omsc.2014.12.001.

8. Parkins GE, Ayettey-Adamafio M, Avogo D, Scheller EL, Pinsky HM. A suspected dental cellulitis leading to diagnosis of both herpes zoster ophthalmicus and HIV. Oral Maxillofacial Surg Cases 2015;1:5-7. https://dx.doi.org/10.1016/j.omsc.2015.03.001.

9. Aresdahl A, Lindell B, Dukic M, Thor A. Congenital granular cell epulis-a case report. Oral Maxillofacial Surg Cases 2015;1:8-11. https://dx.doi.org/10.1016/j. omsc.2015.04.001.

10. Miloro M, Haupt A, Olsson AB, Kolokythas A. Oral spindle cell lipoma: a rare occurrence and review of the literature. Oral Maxillofacial Surg Cases 2015;1:12-4. https://dx.doi.org/10.1016/j.omsc.2015.04.002.

11. Scopus preview: Oral and Maxillofacial Surgery Cases [document on the internet]; 2019 [cited 2019 Jul 18]. Available from: https://www.scopus.com/ sourceid/21100393214.

12. Scimago Journal \& Country Rank: category - oral surgery [document on the internet]; 2019 [cited 2019
Jul 19]. Available from: https://www.scimagojr.com/ journalrank.php?category=3504.

13. DOAJ (Directory of Open Access Journals) [document on the internet]; 2019 [cited 2019 Jul 20]. Available from: https://doaj.org.

14. ScienceDirect: Articles in press [document on the internet]; 2019 [cited 2019 Jul 22]. Available from: https://www.sciencedirect.com/journal/informationand-management/articles-in-press.

15. International Journal of Implant Dentistry [document on the internet]; 2019 [cited 2019 Jul 20]. Available from: https://journalimplantdent.springeropen.com/.

16. Hedlund T, Rabow I. Scholarly publishing and open access in the Nordic countries. Learn Publ 2009;22:177-86. https://doi.org/10.1087/2009303.

17. Crystal D. English as a global language. 2nd ed. Cambridge: Cambridge University Press; 2003.

18. Tymofieiev OO, Fesenko OD, Fesenko II. Transition from Korean to English language of South Korean journals both dedicated to the oral and maxillofacial surgery (OMS): the transitions' impact on OMS residency programs. J Diagn Treat Oral Maxillofac Pathol 2018;2:155-64. https:// dx.doi.org/10.23999/j. dtomp.2018.4.3.

19. Terheyden H, Maeda Y. International Journal of Implant Dentistry. Int J Implant Dent 2015;1:1. https://doi.org/10.1186/s40729-014-0001-z.

20. Gosau M, Viale-Bouroncle S, Eickhoff H, Prateeptongkum E, Reck A, Götz W, Klingelhöffer C, Müller S, Morsczeck C. Evaluation of implantmaterials as cell carriers for dental stem cells under in vitro conditions. Int J Implant Dent 2015;1:2. https:// doi.org/10.1186/s40729-014-0002-y.

21. Wada M, Tsuiki Y, Suganami T, Ikebe K, Sogo M, Okuno I, Maeda Y. The relationship between the bone characters obtained by CBCT and primary stability of the implants. Int J Implant Dent 2015;1:3. https://doi. org/10.1186/s40729-014-0003-X.

22. Hagiwara Y, Narita T, Shioda Y, Iwasaki K, Ikeda T, Namaki S, Salinas TJ. Current status of implant prosthetics in Japan: a survey among certified dental lab technicians. Int J Implant Dent 2015;1:4. https:// doi.org/10.1186/s40729-015-0005-3.

23. Shanbhag S, Shanbhag V, Stavropoulos A. Genomic analyses of early peri-implant bone healing in humans: a systematic review. Int IImplant Dent 2015;1:5. https:// doi.org/10.1186/s40729-015-0006-2.

24. Kimura M, Takasugi Y, Hanano S, Terabe K, Kimura Y. Efficacy of intravenous sedation and oral nifedipine in dental implant patients with preoperative hypertension - a retrospective study of 516 cases. Int J Implant Dent 2015;1:6. https://doi.org/10.1186/ s40729-015-0004-4. 
25. Meisberger EW, Bakker SJ, Cune MS. Temperature rise during removal of fractured components out of the implant body: an in vitro study comparing two ultrasonic devices and five implant types. Int J Implant Dent 2015;1:7. https://doi.org/10.1186/s40729-0150008-0.

26. International Journal of Implant Dentistry [document on the internet]; 2019 [cited 2019 Jul 18]. Available from: https://www.ncbi.nlm.nih.gov/nlmcatalog?term $=\% 22$ Int + J + Implant + Dent $\% 22[$ Title + Abbreviation] .

27. Rhee JS. JAMA Facial Plastic Surgery-The Year in Review, 2018. JAMA Facial Plast Surg 2019;21:183. https://doi.org/10.1001/jamafacial.2019.0043.

28. Bonow RO. JAMA Cardiology-The Year in Review, 2018. JAMA Cardiol 2019;4:406. https://doi. org/10.1001/jamacardio.2019.0033.

29. Öngür D. JAMA Psychiatry-The Year in Review, 2018. JAMA Psychiatry 2019;76:463. https://doi. org/10.1001/jamapsychiatry.2019.0216.
30. Rohrich RJ, Weinstein A. A major milestone for Plastic and Reconstructive Surgery-Global Open: indexing and archiving in PubMed Central. Plast Reconstr Surg Glob Open 2015;3:e297. https://doi.org/10.1097/ GOX.0000000000000261.

31. CiteScore: a new metric to help you track journal performance and make decisions [document on the internet]; 2019 [cited 2019 Jul 18]. Available from: https://www.elsevier.com/editors-update/story/ journal-metrics/citescore-a-new-metric-to-help-youchoose-the-right-journal.

32. Journal metrics in Scopus: Source Normalized Impact per Paper (SNIP) [document on the internet]; 2019 [cited 2019 Jul 20]. Available from: https://blog. scopus.com/posts/journal-metrics-in-scopus-sourcenormalized-impact-per-paper-snip.

33. Journal metrics in Scopus: SCImago Journal Rank (SJR) [document on the internet]; 2019 [cited 2019 Jul 20]. Available from: https://blog.scopus.com/posts/ journal-metrics-in-scopus-scimago-journal-rank-sjr. 